821.163.41.09 Поповић Павле

811.163.41.09:398 Петровић Његош Петар II https://doi.org/10.18485/msc.2019.48.2.ch4

Миодраг В. ЈОВАНОВИЋ*

Оригинални научни рад

Универзитет Црне Горе

Примљен: 03. 11. 2018.

Филолошки факултет

Прихваћен: 14. 02. 2019.

\title{
ПОПОВИЋЕВИ ПОГЛЕДИ И ИМПРЕСИЈЕ О ЊЕГОШЕВОМ ЈЕЗИКУ У МОНОГРАФИЈИ О ГОРСКОМ ВИЈЕНЦУ
}

\begin{abstract}
Иако је Поповићева књига О Горском вијениу имала првенствено за циљ књижевне мотиве (анализу грађе, предмета радње и карактера јунака Његошевог спјева) суптилном уху књижевног критичара заслуга језика за љепоту стихова, ритамске хармоније стиха и стварања особеног Његошевог поетског израза није могла промаћи - зато се, макар и сумарно, више импресијом него темељним лингвистичким анализама, у посљедњем петом поглављу књиге, осврнуо на пјесников језик (дикцију) и љепоте које у њему леже. Поповићеви ставови и грађа коју је дао били су погодни за дубља језичка разматрања о језику Горског вијенияа, па смо се у овом раду бавили: рефлексима јата, јотовањем секвенци сје, дje, судбином сугласника $x$, неким вокалским и сугласничким групама итд.

Кључне ријечи: Павле Поповић, Његош, Горски вијенац, дикција, народни говор, књижевни језик, вокали, консонанти.
\end{abstract}

1.

Ради бољег разумијевања, тачнијег и пунијег погледа на Горски вијенаи, Павле Поповић није хтио да заврши своју монографију О Горском вијениу само са позитивним оцјенама о књижевној вриједности његовој, којом је, како се види из сваког ретка ове расправе, био опчињен. ,Зар не би био скоро грех”, каже аутор, „завршити једну расправу која о лепотама Вијенца говори, а ни речи не рећи о оном што је најлепше у њему?” (Поповић 1999: 145) - то је Његошев језик, који Поповић назива дикцијом, надахнуто закључујући да се баш у њој огледа најјача снага Његошева, „сила ума списатељског”. Ваљала би, каже, „пространа анализа да се све лепо и потпуно избележи и оцени", а своју зналачки одабрану језичку грађу, којом доказује своја мишљења, скромно сматра једном кратком и забавном шетњом кроз Вијенац. Међутим,

*jmisko@ac.me 
како ћемо нашим разматрањима показати, дати материјал и Поповићеви ставови су много вреднији, и погодни за дубља језичка испитивања, много више него што се на први поглед могло претпоставити.

Све личности Горског вијенца, каже Поповић, су из простог народа па оне и морају говорити као прост народ - отуда је „цела дикција Вијенца имала бити народна". Скоро да нема мјеста у Горском вијениу које није очити доказ томе, све од првог до посљедњег призора, од корица до корица књиге „речи, обрти, фигуре, начин и казивања и причања, све је то скроз народно”. „Разговор је пун живописних израза, карактеристичних обрта, локалних алузија, све потпуно народнога кова" (Поповић 1999: 146). То је и сам Вук осјетио, и хвалио као најбољу особину Његошева писања: „Она је одиста у Вуковом периоду, на путу формирања књижевног језика, и код Вука и код Његоша, здрава, пуна, сочна, готово набрекла народна дикција" (стр. 148).

Постављено питање добија још више на значају, ако се узме у обзир да су Његошевом језику и неки лингвисти приписивали наглашене дијалекатске црте: „То је само сирова уско цетињско-његушка дијалекатска грађа” (Младеновић 1989: 224); „Јасно се види да је Његошев језик углавном народни језик и то онакав какав се говори у Црној Гори” (Вушовић 2013: 186). Зато смо у овом раду хтјели да одговоримо на питања: колико је језик овога спјева сагласан са дијалекатском базом којој је Његош припадао, а колико се од ње пјесник удаљавао бирајући лик у складу са Вуковом нормом, или је идући за својим језичким осјећањима, одступајући од правила и свога говора и Вуковог модела, стварао властити поетски израз. Иако се у овакве језичке анализе Павле Поповић није упуштао ипак је увидио да се у јединству свега овога крије непоновљив Његошев пјеснички језик Горског вијенц̧а, а који је осјетио као нешто највредније у овом спјеву.

2.

Ликови Горског вијенца изражавају се врло често пословицама, које се чују и у народу, па овај спјев кипти од народним језиком уобличених пословица, изрека, компарација, прича, парабола. Два писма (везирово и владичино) прави су образац аутору монографије $O$ Горском вијенцу за илустрацију Његошевог „фигурскога и пословичког стила”, уобличеног народном дикцијом.

Један такав стих-пословица, различит од књижевног, па у великој мјери и од народног лика, одмах је уочљив: Видије ли суда од два пића? Глагол видјети је написан са рефлексом дугога јата, умјесто краткога - видије; а у остатку спјева, овај глагол још једанпут: У њих данас овђе видијесмо (стр. $113)^{1}$; што се најлакше може објашњавати, и до сада се објашњавало, метричким разлозима. Међутим, објашњење може бити и другачије: у говору

\footnotetext{
${ }^{1}$ Из грађе коју преносимо из Поповићеве монографије не наводимо број стиха, јер то ни он није чинио; за грађу коју смо, за потребе овога рада и наших анализа, одабрали из других дјелова Горског вијенца редовно се даје и број стиха.
} 
Његошева завичаја, и нешто јужније у савременим црногорским приморским говорима, у овом је глаголу дошло до поремећаја у репартицији рефлекса дугога и краткога јата - па лик видијети напоредо са виђети (чак и нејотованом варијантом видјети) са двосложним рефлексом није необично чути ${ }^{2}$ (Поповић, Петровић 2009: 26; Јовановић 2005: 226).

2.1. Сугласници подложни јекавском јотовању у Горском вијениу се неједнако понашају. Близу ситуацији у народним говорима јесте судбина сугласничке групе дје. Не само у глаголу видјети, за који је највише потврда, дје готово редовно даје Ђе у Горском вијениу и у другим лексемама: А ево сте гори него ђеща! (189); ђед ми га је на сабљу добио (371); Стиже ђеиу родитељска клетва! (697); од богатства бјеху полуђели / Ђетињаху исто као бебе (1410-1411); као у нас бијеле неђеље (1437); Муж је бранич жене и ђетета (2315); што потврђује и грађа коју даје Поповић: у жене му ђеиу скаменио, своју ђеиу на њ печену ио; Како су се душе прађедовске, Тужи млада Ђевера Андрију.

За досљедност спроведеног процеса $\partial j->\hbar$ у језику Горског вијенца потврда су и замјенички прилози за мјесто са секундарним јатом различитог гласовног склопа (прилози за мјесто са партикулом де): ђе, ниђе/нигђе, иђе, свуђе, овђе, онђе: Ђе из мора дођу на гомиле (148); Ђе су царство сабље дијелиле (372); Ђе се виле у шербет купају (914); но понавља оно што ђе чује (2572), да је игђе брата у свијету (647); оградили негђе воденицу (831); кад у кућу нигђе нико нема (1572); Без момчади ове што су овђе (126); Погибосмо овђе чекајући (322); Има онђе и Црногорацах (1761). Такође се налази и у Поповићевој грађи, када се истиче љепота народне дикције (говора): чујем лелек ђе горе пролама.

Секвенцом $c+j e$ од кратког јата писац Горског вијениза иде заједно са Вуковим моделом књижевног језика, а не са стањем у ијекавским говорима. Група сје је иначе у језику високог степена учесталости, па је потврде поменутог стања у језику Горског вијенца, и Поповићевој грађи, било лако наћи: На трон сједиш неправо узети (56); запита ме за наше сусједе (1641); Кад присједох мало украј поља (2555); и сјечењем у опкладу плећах (101); ал' сјекиру чекај међу уши! (768); Чудне стоке, бог их посјекао (2124); Кнеже Бајко, ти си нешто сјетан (1363); код Поповића: у њиву му сјеме скаменио; Нови Граде, сједиш на крај мора / како старац на камен сједећи; ватра гори на сред сјенокоса / украј ватре сједе да се грије. Стих: него пасју вјеру вјеровао (2428) указује и на стабилност групе $c j$ у позицији новог јотовања $(c j<c b j)$.

\footnotetext{
${ }^{2}$ Осим ова два примјера, видјети је у Горском вијениу редовно у јотованом лику: Када виђех витешку невољу (1487); свуд могаше из зида виђети (1539); кад виђеше чудо невиђено (1599); Кад виђели е их погрдише (1610); ја не виђех у једнога момка (1989). У 2. л. императива овог глагола два пута је употријебљен дијалекатски лик виђи: Виђи врага су седам бињишах (1); $B u ђ и$ посла цара опакога (66); али постоји и књижевни: Јере види траг ни ископаше (2157); а за њега, види, није земља (2331). У Горском вијениу је још обичнији дијалекатски лик 1. л. једнине презента - виђу: кад је виђу ђе се смије млада (1279); Сад те виђу на твојега Ждрала (1827); да ти црне очи виђу (1945); већ вас виђу под сјајним покровом (2352); али налазимо и књижевни: да уредбу видим како стоји (1083).
} 
2.2. Када би се на основу првог утиска из грађе коју даје Поповић (из писма везиру, али и на другим мјестима), и уопште из стихова Горског вијенцุa, пресуђивало, рекли бисмо: Његошев језик не одступа много од класичне ијекавско/јекавске замјене некадашњег вокала jam - дуго jam: али капе за по двије главе; а на бријег морски обојица; Смијешане најлакше се пију; очи су јој двије звијезде; под вијенцем гори даница; међ којима каткад сијева; над изијећем плива зорњача; играју се на бијела јата; над образом свијетла језера; на гробљу ће изнићи цвијеће; дријемају у морској тавници; тада она вијенаи расплете; а ја плачем ка мало дијете; кратко jam: Ја се чудим лијепе ми вјере, И звјерад су исто као људи, род свакоји своју вјеру има; сњежна гривна ситна бисера, кад вјетрови и мутни облаци, Кад пред зору, а ноћ је мјесечна, чело јој је љепше од мјесеияа.

Није одлика Његошевог језика употреба рефлекса дугога јата ије умјесто краткога је - код придјева свјетски, ипак потврђена: жертвом на трон бича свијетскога (238); слуга брата сунца свијетскога (1078). А може ли се у стиховима Горског вијенца умјесто двосложне вриједности јата у дугим слоговима, наћи једносложна? Јако ријетко, као у стиху да умјем плакат од радости (2729). То су углавном примјери гдје се за обиљежавање испуштеног вокала $u$ из јатовске секвенце ије употребљава апостроф: не $c$ 'је каљат мјесецослов (Посвета, 27); да ми св’јетли круна Лазарева (784); Мало људство, што си засл 'јепило? (888); пожњеш ми га у изв'јету младости (981). Хвалећи један од највећих Његошевих дарова (а имао их је, истицао је Поповић, много) сликарску страну Његошевог поетског израза, гдје има доста слика и живописних елемената „епских, широких, само крупним потезима рађених а потпуно пластичних" (стр. 162), он наводи ове стихове: $Б$ 'јеле власе низ плећи просуо / Б’јела брада вије до појаса; б’јеле руке крила лабуда.

2.3. „Необично лепа компарација кад владика види да мора бити рата у којем ће многа младост погинути": Младо жито, навијај класове, / пређе рока дошла ти је жњетва, / Дивне жертве видим на гомиле / пред олтаром цркве и племена, чујем лелек ђе горе пролама (стр. 157-158) покренута је употребом народног лика прилога прије - пређе. Различитим фонетским реализацијама прилога (и предлога) прије Његош користи све могућности свог народног говора - приће је најчешћа варијанта: Приђе си им с коца утекао (543); свакога ми узе приђе рока (978); да ђавола приђе у њих видиш (1728); но ће приђе море ослачати (1831); приђе но смо легли и заспали (2243); Најприђе ти Божић честитамо (2587); а само је једном горе наведеним стихом потврђено и у црногорским говорима веома продуктивно пређе.

3. Стихом-пословицом: Оли челе хватат у капицу, из везировог писма владици, пропратићемо двије фонетске црте, са различитом реализацијом - једна према моделу народних говора $(n \varphi>4)$, а друга књижевног језика (стабилна сугласничка група $x в$ - и на другим мјестима у Поповићевој грађи: Бјеше облак сунце ухватио). Неизмијењена група $x в$ не одговара приликама у Његошевом завичајном говору, гдје је редовно прешла у $ф$ (и код хват- и код хвал- основа) - у Горском вијениу је редовно у књижевном лику: и свакоју живу ухватисмо (191); а не бисте ниједну хватали (195); Ко се топи хвата 
се за пјену (539); Домамили па их похватали (1449); Докле свако за по грозд ухвати (1597); и кулу му бјеше дохватио! (2772) // Хвала богу, велике жалости (1964); Ефендија, овако ти хвала! (934); Хвала богу има ли вјештицах? (2173). Међутим, код хвал- основа постоји и један изузетак - хв- је прешло у $\phi$, као и у народном говору: Фала богу, јест велико чудо! (1674).

3.1. Његош је, сматра Поповић, приближавањем народном говору погодио фамилијарни начин изражавања - у Вијениу „често, место коректног књижевног облика долази казивање фамилијарно, на прескок, онакво како се води на улици, скоро небрижљиво; и то даје стилу много више живости и оригиналности" (стр. 147). Питање је да ли овој констатацији може потпуно одговарати редовно писање финалног $x$ у грађи коју износи ${ }^{3}$ џефердара $\partial p$ жах пред очима; мало руках, малена и снага; како јата дивних ${ }^{4}$ лабудовах; Сто nутах сам у својој младости; вјешти звуци дивнијех гусалах; насрка се дима с жертвениках; Паде Милош чудо витезовах; страшном мишљу, прсих надутијех ${ }^{5}$. Мало има дијалекатских особина које би у Његошевом језику биле потпуно досљедне, а о једној таквој с највећом поузданошћу можемо говорити. Увијек је ген. множине именица било које врсте промјене у облику са сугласником $x$ на крају: сто путах сам гледао облаке (147); часне двоје постах да постите (861); Јошт имате земље и овацах (1165); нема пуно осамнаест sетаx (1266); У то доба пет Мартиновићах (1320); ја сам више у царство духовах (2255). Сугласник $x$ без изузетка је и дио наставка замјеничко-придјевске промјене -ијех: и с ломљавом страшнијех громовах (152); шест нашијех, девет юиховијех (419); Бјеше, брате, доста лијепијех / а грднијех десет путах више (1406-1407); Такве бруке, таквијех грдилах (1552); из онијех пањегах завика (1563); Има, кнеже, некијех рогошах (2174); из гробовах нашијех ђедовах! (2617); но стотину тијех бројаницах (2240). И уопште у финалној позицији: славом бојном ғих опио (Посвета, 7); Грдне треске поврх Љешкопоља (703); или имах китнога вијенца (979); знао бих ти одговорит дивно (1186); обећа ми и што му не исках! (1655); И помислих кад од њега пођох (1656); а нијесу да $u x$ покољете (197); Да радимо да $u x$ помиримо (728).

3.2. Укупној ситуацији и оцјени о финалном $x$ у потпуности одговара и судбина иницијалног и медијалног: Соко хоће високу литицу; из миндера у зору хитао; скаче старац како хитро момче; Најсветије небесне храмове // једна сламка међу вихорове; бојаху се сунца и мјесеца; бјеху мушка прса охладњела - стање које осликава Поповићева грађа, потврђују и други сти-

\footnotetext{
${ }^{3}$ Ипак, Михаило Стевановић сматра да су се ови облици у Његошево вријеме у говору његова ужег завичаја (Његуши) изговарали с гласом $x$ нормалне артикулације, односно да Његошев језик потврђује стање у народним говорима (у свим позицијама у ријечи) (Стевановић 1990: 220-223).

${ }^{4} \mathrm{C}$ обзиром на укупну ситуацију са генитивом множине у Горском вијениу неочекиван је примјер са новијим образовањем према књижевном језику (дивних) - наравно, и овдје са реализованим финалним $x$.

${ }^{5}$ Стабилан је сугласник $x$ у финалној позицији и у узвицима: $O x$, да ми је очима виђети; - у ријечима које су недовољно семантички одређене, „условни језички знаци” (Белић 1958: 77-79), а које писац Горског вијенци, због постизања дубље емоционалности, зна употријебити - и то увијек са писањем $x$ : да очешљам дуги перчин! / jaох мени! (1946); Ox до бога, а ох довијека (1966); Ух што мислим, куд сам запливао? (651).
} 
хови из Горског вијенияа: а с најгорим хоћу да се борим (46); па је Драшко у Млетке ходио (1396); из миндера у зору хитао (921); Него хајте, од земље главари (723); да истрчеш хата крилатога (1809); Он је хајдук робља свезанога (1189); да ничега, ано свога хлада (1504); три хиљаде момка једнакога (1063) // је ли инстинкт ал' духовни вођа (614); И што ми је до ґихове свађе (1204); од бруке се гледат не могаху (1408); Једни сужњи бјеху приковани (1466); Лијево ми ухо сад запоја (950); имах мртав паднут од смијеха! (1549); раније си свагда доходио (2527); пробуди му бухе у кожухе (1851); од њих свако у Млетке дрхташе (1507); Ко је оно, ка да су махнити? (1755). Ријетки су у Горском вијениу примјери без $x$, али ипак потврђени - углавном у иницијалној позицији: крвника га ришћанскога нема (1911); што им оће друштво са Турцима? (1765); аљьинах је на небеса доста (2226); а у једном стиху и у медијалном положају испред сугласника: Ти нијеси саморана глава (110); који и Поповић издваја (стр. 162), оцјењујући како је говор Вука Мићуновића, његово обраћање владици, прошаран њежним ријечима, јунаку којему се ове особине ријетко приписују: „да није неколико места у којима Мићуновић покаже своју лавовску шапу, не би човек рекао да ово све он говори. Изгледа да говори чедна девојка, горска вила, муза која тихо шапће наду и утеху на ухо песнику, или мати која говори детету”. Баш таквог га Поповић доживљава и у другим приликама - у Мићуновићевом одговору владици: Не владико ако бога знадеш, гдје „нема ничега суровог, увредљивог, дивљачног; све благо, питомо, нежно” (стр. 160). И када говори о „врсним момцима”, о момчадији у коју се ваља уздати и ту неће да у први план ставља ратоборност или крвожедност момака, него на здравље њихово, на „снагу”, „лакоћу”, „брзину”, „вјештину”, „хитрину” само таквим ријечима је окарактерисана младост црногорска. И још је ова младост представљена као питома, чедна, побожна, хришћанска, која смирено иде у цркву и слуша „божју летурђију”, која само „око цркве” води коло кад га једанпут поведе, којој је „тамјан” што и витештво, која због цркве иде у рат. „Такву, ето, благу и утешну слику износи Мићуновић владици пред очи” (стр. 161).

4. Друга фонетска црта из стиха-пословице: оли ${ }^{6}$ челе хватат у капицу, упроштавање групе $n \varphi>$, свакако је из дијалекта. Заједно са народним говорима, много шире распрострањености него што је Његошев, иде судбина сугласничких група $n ч-, n m-, n u-$, које су испадањем иницијалног $n$ у Горском вијениу редовно упроштене: Али тице те су најслабије (772); соко тражи тииу јаребицу (1877); као једна прекоморска тица (2573) // пресули их бијелом шеницом (2441).

5. Најзад, да се осврнемо и на још један стих-пословицу из везировог писма владици - но што стрепи лаф од гуске? кажи; јер је у Горском вијениу досљедно $\phi$ умјесто в у финалној позицији у лексеми лаф < лав, што као необичнију варијанту потврђују и неки народни говори (црмнички) и језик писаца (Стефан Митров Љубиша): бораше се као лаф с Турцима (568); но

\footnotetext{
${ }^{6}$ И упитни облик 2. л. јд. презента глагола хтјети (у вези са ли) о-ли (<хоћещ-ли) је у духу народног говора, a „x cе у хоћy раније изгубило него у другим позицијама” (Пешикан 1965: $36,171)$.
} 
што стрепи лаф од гуске, кажи? (805). Штавише, сугласник $\phi$ се, по узору на финалну, усталио и у медијалној позицији: Из грмена великога лафу изаћ трудно није (Посвета, 9); постадоше лафи ратарима (259); малом мраву ка гордоме лафу (756).

6. То што Петар II Петровић Његош даје чисти народни колорит дикцији je, оцјењује Павле Поповић, „ретка и тешка ствар", а за потврду ове импресије добро му је дошла прича Вука Мандушића с краја спјева, како му је пребијен џефердар ${ }^{8}$ : А у раздвој боја крвавога / најпотоња која пуче турска / џефердара држах пред очима / престриже га остала му пуста! / по ремику ка да трска бјеше. Остављајући по страни оригиналност (,раздвој”, „престрићи”), тачност компарација (,ка да трска бјеше”) које указује на одступање од обичног реда, који би у свакодневној комуникацији логично био: најпотоња која пуче турска / престриже га / по ремику; Поповић жели да слободу изражавања, инверзију обичнога реда, подреди значају ванредне дикције (jeзика) која повећава рељефност слике и причање приближава фамилијарном. А таква је употреба поредбеног везника, односно прилога, као у стиху: по ремику ка да трска бјеше, који је и у његушком говору готово редовно у лику насталом прогресивном асимилацијом - као > ка. „Опис снахе Милоњића бана која је у ведрој јесењој ноћи тако елегантна, етерична, чисто прозаична” (стр. 163) потврђује лик из дијалекта: а ја плачем ка мало дијете; и другдје у Поповићевој грађи као > ка: ка кад зраке умру на планину; ка малопр’јед што гордо иђаше. И укупно је у Горском вијениу лик народног говора ка много чешћи од књижевног (али ни употреба нормативног није занемарљива): но, ка пашче кад га за тор свежеш (1472); момци дивни исто ка звијезде (270); ка је она пјесна изведена (292); Што је човјек? Ка слабо живинче! (763); ка у сахан што се чорбе слажу (1021); ка невјерној кући Бранковића (1054); особено ка што је код тебе (2481) // А ево смо као они миши (434); као некуд да крсте носимо (1310); као цукар свака бјеше слатка (1318); па иђаху као на кључеве (1558).

6.1. Не само у везнику-прилогу као, у говору Његошевог завичаја, и уопште у староцрногорским говорима, код вокалске групе -ао на крају ријечи долази до уједначавања артикулације у правцу вокала - $($ доша, njeва, река, чита). И у Његошевом језику имамо често такав лик: и утека с братом најмлађијем (471); али ко би мога помислити (474); Ја сам Озра ноћас на сан гледа (1341); приправља сам што мрцу требује (1372); Ја сам много обиша свијета (2259); разгледа сам и све три пећине (2267). Али подједнако је чес-

\footnotetext{
7 Учестало указујући на лијепу страну Његошеве дикције, уобличену народним колоритом, Поповић је препознао и показао сличност између Горског вијенца и стихова IV збирке Вукових пјесама - у Вијениу: распале ме ужаса пламови; код Вука: сад с' у мене распале пламови; у Buјениу: шћаше ли им вјера мила бити / да издижу мирно у Рудине; код Вука: да од мира вјеру ухватимо / да издигнем овцам у Рудине; у Вијениу: крвника га ришћанскога нема / заклала га пушка црногорска; у пјесми то исто (стр. 161 - фус. 82).

${ }^{8}$ У овој лексеми је у Горском вијениу, као и у његушком говору, стабилна употреба сугласника $\phi$ : а цефердар Томановић Вука (141); нит' се ломе такви цефердари (2743). У језику Петра Првог, па и Његошевог савременика Стефана Митрова Љубише имамо дублет цефердар/цевердар (Остојић 1976: 103; Тепавчевић 2010: 163); ово је одлика и Његушима сродног црмничког говора (Милетић 1940: 360).
} 
та, ако не и обичнија, употреба књижевног лика: У небу сам, у мору, гледао (925); да не држим, бих се избљувао (1247); деветороструко кумовао (1272); а он ме је братски дочекао (1443); Он не бјеше но само настао (1994); Ја ти не бих предавао бира (2074); Ко издао, браћо, те јунаке (2421); од милине уру сам слушао! (2576). Дакле, Петар II Петровић Његош је и дијалекатски и књижевни лик имао у свом језичком осјећању и употребљавао их у стварању свог непоновљивог стиха. У другом игумановом монологу „Ја сам проша сито и решето, / овај грдни свијет испитао” Поповић осјећа „леп ритам”, „где се мешају философија и познавање живота и узимају облик ванредно јаких сентенција" (стр. 152), које Његош исказује различитом реализацијом финалне вокалске скупине -ао на крају ријечи - напоредо, у дијалекатском и књижевном лику: проша/испитао.

7. У стиху: Земља стење а небеса ћуте Поповић види, како је сам изразио дивљење, огромну слику пуну високе лирике - „оно величанствено 'небеса ћуте', не 'небо' него 'небеса'. Ово је један од оних огромних стихова који у трен ока обухватају оба пола светска" (стр. 153). Његош употребљава проширену множину именица небо и чудо (поред небо: нада мном је небо затворено; и чудо: Паде Милош чудо витезовах) - лексема небеса потврђена је великим бројем примјера, а једним и чудеса: Земља стење, а небеса ћуте (630); уз веселе зраке на небеса (997); аљинах је на небеса доста (2225); на милост ће окренут небеса! (2360); у њ ратују дуси с небесима (2510); колебљу се у мору небеса (2514); Пушке грме, небеса се ломе (2559); Плам се дига бјеше у небеса (2771) // ви сте ближе бога и чудесах (2230). Од небеса придјев је редовно небесни: за Егиста управ слични гром небесни, суд Орестов (Посвета, 28), ал' небесну силну зраку што ћ' угасит твоје душе? (30); Који сједиш на престол небесни (743). Наведени ликови с проширењем -ес- у множинским падежима афективно се могу употријебити и у говорима Његошевог краја, али и у областима много удаљеним од њих.

8. Нема сумње, примјећује Поповић, Његош је био много више него прост народни пјесник, којега су многи философски и морални проблеми занимали - био је филозоф-пјесник. „Дело које је дотле садржавало само тачно ухваћене разговоре и причања безазлена света, открива одједном карактер високих лирских тема. Дикција Вијенца одједном постаје узвишена лирика" (стр. 150). „Говорио владика, или игуман, или главари, или прост народ, увек ce, посред просте народне фразеологије, укаже која висока идеја, рефлексија, медитација, у беспрекорној форми античке сентенције, високе химне, узвишене оде. По целом ткиву народнога говора просут је бисер овакве поезије. Таквим је пасажима прошаран Горски вијенац. Позната места, просте идеје узете од народа постају оде, добијајући достојанство високе филозофске (и религиозне) медитације". На тај начин, кад је у рукама великог пјесника, једно просто народно казивање нарасте до ванредно јаког лирског пасажа. И наводи једно познато мјесто из монолога Игумана Стефана, са понављањем фразе $y$ ғ ратује/ратују. Каденцијама: $y$ њ ратује душа са тијелом, / у њ ратује море с бреговима, / y њ ратује зима и топлина... „помаже се и даје одсечности, наглашавања, јачег израза”, све су то, задивљен је Поповић, „савршени 
обрасци стила, класични пасажи Вијенца, бесмртна сведочанства високе поезије Његошеве" (стр. 152). Ван овог монолога само су два стиха са њ : Ую се осам близанацах (Посвета, 3); своју ђецу на њ печену ио (2431). Енклитички облик личне замјенице 3. лица њ уз предлоге ушао је у књижевни језик из народних говора динарских крајева, из којих се стално обнавља. При томе, у Вуково је вријеме (и кроз цијели 19. и прве деценије 20. вијека) облик н био често граматичко (можда и стилско) средство књижевника (Стевановић 1963-1964: 86-87).

9. Народни колорит је највећа љепота језика Вијенца - потврдиле су наше анализе Поповићев основни суд. Међутим, како је он такође запазио, Његош је својим језиком много више него прости народни писац. Иако је Поповићево бављење Његошевим језиком било „само шетња кроз Вијенаи”, и оно што је у посебном поглављу монографије $O$ Горском вијениу дао довољно је да предочи читаоцу како је језик овог спјева пун високе лирике, што Његоша доводи до круга највећих свјетских пјесника. Поетичност Његошевог израза јесте у прожимању црта народног и књижевног језика што смо показали анализом грађе коју је Поповић дао својом „шетњом кроз Вијенаи”. Тако смо, да пренесемо одушевљеност Павла Поповића Горским вијенцем „дотакли многе дирке у намери да пробамо звук, и на све њих дух нашега песника одјекнуо је као какве силне, огромне оргуље".

\section{ЛИТЕРАТУРА}

Белић 1958: Александар Белић, О језичкој природи и језичком развитку, I. Београд: друго издање.

Вушовић 2013: Данило Вушовић, О Његомевом језику. Никшић: Слово (часопис за српски језик, књижевност и културу), бр. 42, 172-192.

Јовановић 2005: Миодраг Јовановић, Говор Паштровића. Подгорица: Универзитет Црне Горе, Библиотека Филозофско-филолошке науке, штампа „Графичар” - Ужице.

Милетић 1940: Бранко Милетић, Црмнички говор. Београд: СДЗб IX.

Младеновић 1989: Александар Младеновић, Кюига о Његошу. Београд: НИРО „Књижевне новине”, Горњи Милановац: НИРО „Дечје новине”.

Остојић 1976: Бранислав Остојић, Језик Петра I Петровића. Титоград: ЦАНУ Пос. издања, књ. 8, Одјељење умјетности, књ. 1.

Пешикан 1965: Митар Пешикан, Старочрногорски, средњокатунски и љешански говори. Београд: СДЗб ХV, 1-294.

Поповић 1999: Павле Поповић, О Горском вијенцу, Подгорица: Октоих (Библиотека Његош).

Поповић, Петровић 2009: Момчило Поповић, Драгољуб Петровић, О говору Спича (грађа). Београд: САНУ и Институт за српски језик САНУ, СДЗб LVI, 1-275. 
Стевановић 1963-1964: Михаило Стевановић, Језик у Вукову делу и савремени српскохрватски књижевни језик. Београд: ЈФ XXVI, св. 1-2, 73-150. Стевановић 1990: Михаило Стевановић, О језику Горског вијенца, Његошев књижевни језик. Београд: САНУ, Научна књига.

Тепавчевић 2010: Миодарка Тепавчевић, Језик Стефана Митрова Љубише. Подгорица: ЦАНУ, Посебна издања (монографије и студије), књ. 70, Одјељење умјетности, књ. 19.

\author{
Miodrag Jovanović
}

\author{
POPOVIĆ' VIEWS AND IMPRESSIONS ON NJEGOŠ' LANGUAGE \\ IN THE MONOGRAPH ON THE MOUNTAIN WREATH
}

(Summary)

Since all of the characters from The Mountain Wreath originated from simple folk, they had to speak (and do speak) as simple folk - is Popović' dominant view on the language of Njegoš' work. What is more, he indicated that the folk dialect is the most significant feature of the language of the Wreath, but there is something more that he presented using specifically chosen material in a particular chapter of the volume On the Mountain Wreath, and that is now Njegoš and his language indicates that he is much more than a simple folk author. We have, working with the material provided by Popovic, but also relying on overall insight into the entirety of The Mountain Wreath, analyzed several linguistic features: the reflex of jat, consonants palatalized before $j$ in groups of consonants such as dje and sje, the fate of the consonant $h$, the vowel group -ao, certain groups of consonants, etc. Our analyses have indicated that the dialectical note in Njegoš' language is quite prominent; however, these features are never solely local (originating from the village Njeguši), but are instead always a part of a broader region. At the same time, the poet-author of The Mountain Wreath when choosing between the dialectological and literary character often selects the latter - thus, in constructing its idiosyncratic poetic language Njegoš relies on both the dialectical and literary form. The fact is that the language of The Mountain Wreath brings it closer to the work being done by Vuk and to his model of the literary language, at the same time distinguishes it frommost of the Montenegrin dialects of the time. Pavle Popović considered his chapter on diction a "short and entertaining stroll through the Wreath", while it turned out that it is much more than that. Our paper has, in addition to linguistic analyses, also provided a way back to Popović' impressions and the revival of his views of the language of The Mountain Wreath, expressed at the beginning of the $20^{\text {th }}$ century. 